\title{
(IN)VISIBILIDADES IDENTITÁRIAS EM TENDA DOS MILAGRES E OMEROS
} IDENTITY (IN)VISIBILITIES IN THE TENT OF MIRACLES AND OMEROS

\author{
Renato Gonçalves Peruzzo ${ }^{1}$ \\ Isaías Francisco de Carvalho ${ }^{2}$
}

Resumo: O trabalho empreende a análise dos aspectos da construção das sociedades baianobrasileira-caribenha, no âmbito do Caribe Estendido, tomando por corpus as obras literárias Tenda dos Milagres, de Jorge Amado, e Omeros, de Derek Walcott. O aporte teórico, inserido no campo dos estudos culturais pós-coloniais, inclui estudos acerca da subalternidade e da outrização e o conceito-atitude de outrização produtiva como operadores de análise dos grupos culturais que foram (e ainda são) estigmatizados e silenciados, mas que puderam, literariamente, ter espaço de representação. De cunho descritivo-bibliográfico, estuda as questões de subalternidade, língua, silenciamento e, por conseguinte, possibilidade de fala.

Palavras-chave: outrização; outrização produtiva; identidade; Caribe Estendido.

Abstract: This paper undertakes an analysis of the construction aspects of Bahian-BrazilianCaribbean societies, within the extended Caribbean, taking as a corpus the literary books Tent of Miracles, by Jorge Amado, and Omeros by Derek Walcott. The theoretical contribution, part of postcolonial cultural studies, includes studies of subalternity and othering, and conceptattitude of productive othering as operators of analysis of cultural groups that were (and still are) stigmatized and silenced, but that could have space of representation through literature. From a descriptive-bibliographic perspective, studies the questions of subalternity, language, silencing and, consequently, the possibility of speech.

Keywords: othering; productive othering; identity; Extended Caribbean.

\section{Introdução}

A pesquisa aborda as identidades de grupos sociais silenciados e estigmatizados, portanto invisibilizados, mas que puderam ser literariamente apresentados e representados por

\footnotetext{
${ }^{1}$ Doutorando em Letras: Linguagens e Representações, na Universidade Estadual de Santa Cruz - UESC. Tem bolsa de financiamento implementada pela CAPES. Participa dos Grupos de Pesquisa (CNPq) Estudos em Línguas e Literaturas Estrangeiras; e Literatura, História e Cultura: Encruzilhadas Epistemológicas. É licenciado em Letras, com habilitação em Língua Portuguesa, Língua Inglesa e suas respectivas literaturas pela Universidade Estadual de Santa Cruz - UESC. E-mail: naticos15@gmail.com

${ }^{2}$ Doutor em Teorias e Crítica da Literatura e da Cultura pela Universidade Federal da Bahia - UFBA. Professor de Literaturas Anglófonas e de Língua Inglesa do Departamento de Letras e Artes da Universidade Estadual de Santa Cruz - UESC, vinculado aos Programas de Pós-graduação em Letras: Linguagens e Representações e Mestrado Profissional em Letras - PROFLETRAS. E-mail: isaiasfcarvalho@gmail.com
} 
meio de seus autores. Este artigo é um estudo sobre a construção identitária das sociedades baiano-brasileira-caribenha, por meio da análise das obras literárias Tenda dos Milagres, de Jorge Amado (2008), e Omeros, de Derek Walcott (1994). Incluem-se análises acerca da subalternidade e da outrização (SPIVAK, 1985), que são processos de apagamento ou rebaixamento de uma cultura ou grupo em função de outro grupo ou cultura.

Além dos processos de invisibilização, há a análise a partir do conceito-atitude de outrização produtiva (CARVALHO, 2012), que é entendido como uma ressignificação do processo sofrido, em que as culturas (in)visibilizadas passam a ter oportunidades de voz e de vez nas obras literárias estudadas.

Este trabalho possui um caráter descritivo-bibliográfico de ordem qualitativa, estando inserido no campo de estudos culturais pós-coloniais abrangendo duas obras de países colonizados pertencentes ao âmbito do Caribe Estendido (WALLERSTEIN, 1974), no caso, o Brasil e Santa Lúcia (doravante Saint Lucia). Não seria coerente tratar as literaturas produzidas por países ex-colônias por meio dos pressupostos estruturalistas euro-ocidentais, como salienta Bonnici (2009), pois essas literaturas estão carregadas de conteúdos culturais particulares de suas nações e também de suas reivindicações quanto ao processo colonial vivido. Portanto, dáse o nome de pós-coloniais àquelas teorias que abrangem a cultura e a literatura e que atendem às necessidades de abordagem desses produtos literários e sua inserção no tecido social.

Tendo isso em vista, o Caribe Estendido (Figura 1) pode ser entendido como uma área que compõe uma cartografia imaginada correspondente ao espaço que compreende a linha da costa sul dos Estados Unidos até o Recôncavo da Bahia, abrangendo geográfica e culturalmente os locais de produção das obras analisadas neste artigo. 
Figura 1 - Caribe Estendido

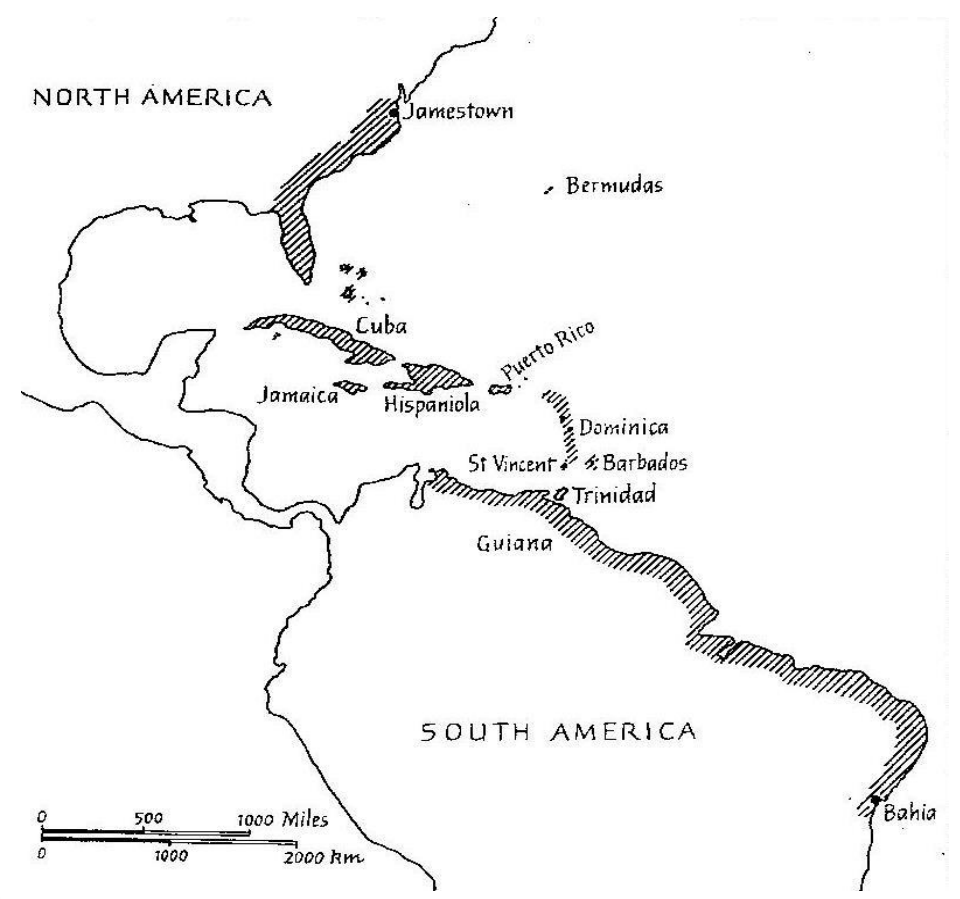

Fonte: WALLERSTEIN, Immanuel apud HULME, Peter. Colonial encounters: Europe and the native Caribbean - 1492-1797. Londres/Nova York: Routledge, 1992. p. 4.

Por sua inserção na área de conhecimento e pelo objetivo delineado, este estudo se constitui uma contribuição para área das teorias culturais pós-coloniais, além de poder ser considerado como resultado de outrização produtiva per se. De fato, destacam-se as formas de outrização presentes nas obras Tenda dos Milagres e Omeros contextualizando-as com suas produções e a teoria aplicada para análise. Segue-se a análise dos processos de outrização produtiva, exemplificados com excertos das obras analisadas e de seus personagens, que servem como exemplos da produção de visibilidade. Também são discutidas questões acerca dos autores como "instrumentos" que concedem espaço de vez e voz aos povos colonizados.

\section{A Tenda dos Milagres outrizada}

Português não admitia Que num grupo de escravos

Existissem diferenças [...]

Que embora semelhantes

Era fator determinante

Donde o negro foi tirado

Antônio Vieira, Akará-jé o mesmo que comer fogo 
Jorge Amado inicia o livro Tenda dos Milagres situando o leitor no ambiente onde as narrativas acontecem. A história se passa praticamente toda no Centro Histórico de Salvador, sobretudo no bairro do Pelourinho. Segundo a narrativa, naquele amplo território, "homens e mulheres ensinam e estudam" (AMADO, 2008, p. 11) e essa vasta universidade contempla muitos outros lugares além daquele, onde "criaram uma cor e um som, imagem nova, original", também um local de nascimento e criação da arte.

Nesse espaço, vários personagens assumem participações na grande trama de Tenda dos Milagres. Dentre eles, o protagonista da narrativa: o negro mestiço Pedro Archanjo, que nasceu em 1868 e faleceu aos 75 anos. A história contada por Jorge Amado é cronologicamente nãolinear, assumindo a perspectiva sequencial dos capítulos, pois a história está voltada para um tempo muitas vezes desconectado ou diferente do capítulo anterior. No entanto, todo o romance é situado em dois eixos temporais: o primeiro é a narrativa dos momentos em que Pedro Archanjo ainda está vivo, contando a sua história e sua trajetória acerca da mestiçagem; o segundo eixo temporal contempla, portanto, os acontecimentos que ocorrem após sua morte, já no momento próximo à comemoração de seu centenário.

Archanjo era bedel (funcionário subalterno que atua como disciplinador em sala de aula e também atua na área administrativa) da Faculdade de Medicina e era também um estudioso autodidata, conhecedor de diversas línguas, tendo escrito quatro livros publicados na simplória tipografia de seu amigo Lídio Corró. Além desses atributos, existem suas descrições pessoais que representam sua total humanidade, incluindo defeitos e qualidades: “[...] de muita sabedoria e esperteza, de bom conselho e experiência, conversador de fama, bebedor de marca, mulherengo até o fim, pródigo fazedor de filhos, preferido dos orixás, confidente dos segredos, um velho tio do maior respeito, quase um feiticeiro, Ojuobá." (AMADO, 2008, p. 44).

Além de toda sua fama nas ruas do Pelourinho, o protagonista encontrava em seu caminho pessoas que não gostavam dele, como o acadêmico Luiz Batista, que numa cena de um bar questiona a seu amigo de copo e ao garçom num tom de ironia e sarcasmo: "Quem foi esse tal Archanjo? Alguma figura exponencial, um professor, um doutor, um luminar, um prócer político, ao menos um comerciante rico? Nada disso: um reles bedel da Faculdade de Medicina, pouco mais que um mendigo, praticamente um operário.” (AMADO, 2008, p. 51).

A diferença entre as descrições é visível: o narrador apresenta os "defeitos" pessoais de Pedro Archanjo em meio à descrição de suas características gerais, enquanto que a fala do 
acadêmico é carregada de um sarcasmo que invisibiliza a pessoa sobre a qual eles estavam conversando, desmerecendo-a (outrizando-a).

Dessa forma, Luiz Batista serviu à narrativa como um exemplo da sociedade da época, impregnada pelo arianismo - crença de que os negros eram inferiores e que ser mestiço seria o fruto de um desequilíbrio entre as raças superiores (brancas) e inferiores (negras) -, pois esse pensamento, resultante dos processos de colonização, não admitia um sistema de equilíbrio hierárquico nas relações econômicas, sociais e culturais entre o colonizador e o colonizado (MEMMI, 2007).

A sociedade daquela época - e de outras - silenciava e invisibilizava aqueles que não eram tidos como pertencentes ao padrão eurocêntrico do homem branco, discutido por Bonnici (2009, p. 262), pois entre “[...] o colonizador e o colonizado havia o fator raça, que construía um relacionamento injusto e desigual". Por conta dessa hegemonia europeia, o regime escravocrata foi implantado nas sociedades colonizadas, permanecendo após a própria libertação dos escravos, pois, ancoradas nas teorias científicas de evolução das espécies, em que " $[. .$.$] se formou a ideia de um mundo colonial habitado por gente 'naturalmente' inferior,$ programada pela natureza para trabalhar braçalmente e servir ao homem europeu branco".

Essa concepção de inferioridade e função natural de ser trabalhador braçal é também representada pela resposta dada pelo professor Viana, diretor da Faculdade, quando solicitado a colaborar para a publicação das obras de Pedro Archanjo. Ramos, o personagem que solicitou a colaboração, quanto àquele momento do pedido, diz que recebeu a resposta de que "“[...] estava perdendo o tempo com as baboseiras de um negro bêbado. Bêbado e subversivo'." (AMADO, 2008, p. 28), o que corrobora o pensamento corrente na época de que negros e mestiços não teriam direito à educação. Por conta da crença de que negros não fazem ciência, Pedro Archanjo não era reconhecido ou auxiliado pela sociedade, nem mesmo pela faculdade em que trabalhava.

A narrativa deixa claro que os professores se sentiam ameaçados pelas vontades de Archanjo de escrever livros e publicá-los. Por isso, desencorajavam-no com o objetivo de tirar essa ideia de sua cabeça. No entanto, Pedro Archanjo, muito sábio, observou durante muito tempo a sociedade onde estava inserido e, tomando-a como objeto de estudo, publicou seus quatro volumes a duras penas. 
Próximo à comemoração do centenário de Archanjo, já morto, é apresentada à sociedade brasileira a importância dos livros do falecido escritor através do americano, laureado pelo Prêmio Nobel, James D. Levenson, pois foi necessária a sua vinda "[...] para que eles se convertessem e assumissem o comando da tardia glória de Archanjo." (AMADO, 2008, p. 55). Embora, como critica o professor Ramos, tal qual a obra de Pedro Archanjo, é "[...] a obra de Levenson igualmente mal conhecida no Brasil e esses que tanto o elogiam e adulam não leram sequer seus livros fundamentais".

Há, aqui, uma crítica feita por Jorge Amado, pois o real valor dos escritos já Ramos "[...] afirmara e exaltara em artigos nas revistas especializadas, infelizmente de quase nenhuma circulação e menor leitura" (AMADO, 2008, p. 27). No entanto, se tornou um "corre-corre" após as declarações do estrangeiro - mal conhecido, mas Prêmio Nobel - que declarou serem importantes as obras do mestiço que pesquisou a vida popular, a mestiçagem e as influências africanas na Bahia. Além disso, Levenson considera os volumes de Archanjo como "livros imperecíveis" e pretende inclusive traduzi-las para o inglês.

Enquanto esteve vivo, Pedro Archanjo também teve suas obrigações com o candomblé, inclusive era descrito e conhecido como "[...] preferido dos orixás, confidente dos segredos, [...] quase um feiticeiro, Ojuobá." (AMADO, 2008, p. 44). Por conta disso, foi o encarregado do primeiro dos afoxés pela Mãe Majé Bassã. De acordo com ela, "[...] sem ele [o afoxé] ou outro igual em fundamento, nenhuma folia ou troça de Carnaval deve sair à rua nem atreverse.” (AMADO, 2008, p. 69), pois significa encantamento - prática ritual do candomblé (BASTIDE, 2001).

Essas festas em momentos de carnaval - afoxés - foram proibidas de sair às ruas “[...] 'por motivos étnicos e sociais, em defesa das famílias, dos costumes, da moral e do bem-estar público, no combate ao crime, ao deboche e à desordem"” (AMADO, 2008, p. 67). A justificativa dada para o impedimento da cultura do candomblé nas festas de carnaval corrobora com o dito por Bonnici, de que houve a criação de "[...] um sistema mundial no qual certas culturas e sociedades eram consideradas essencialmente inferiores." (BONNICI, 2009, p. 264).

No caso da narrativa de Tenda dos Milagres, o afoxé era visto pela sociedade e pela polícia como uma representação cultural inferior, apenas por ser parte do candomblé e majoritariamente negra.

\section{A busca de identidade em Omeros}




\begin{abstract}
Mas quando chegaram aqui
Escravizados, cativos

Sem armas para lutar $[\ldots]$

Sem nenhuma condição

De cultuar os seus santos

Considerados pagãos

Tinham que ficar no canto
\end{abstract}

Antônio Vieira, Akará-jé o mesmo que comer fogo

Após a Segunda Guerra Mundial, período de forte independência em países colonizados, como as nações caribenhas, surgiu uma literatura escrita pelos próprios nativos desses países, como apresentado por Bonnici (2009). A poesia de Derek Walcott encontra-se situada nesse espaço político-literário. Sua obra mais conhecida internacionalmente - Omeros - é um poema “de escopo e proporções épicas” (VIZIOLI, 1994, p. 7-8), pois o tratamento dado, a construção dos personagens e o próprio tema são (quase) todos característicos de uma epopeia.

Os temas abordados nessa "epopeia das Antilhas" são diversos, incluindo tópicos como as questões raciais, identidade do povo caribenho, religião, folclore local etc. Há em Omeros uma mistura poética entre o próprio eu e a terra descrita, em que sobressaem as questões das identidades do próprio autor do poema, da sua origem, das pessoas representadas pelos personagens e da própria história do Caribe.

Acerca das Índias Ocidentais, termo que se refere às ilhas caribenhas, Bonnici esclarece que

\begin{abstract}
A população atual das Índias Ocidentais veio da África, Índia, Oriente Médio e da Europa, e é o resultado do deslocamento, do exílio ou da escravidão. Entre todas as sociedades colonizadas, talvez a sociedade caribenha seja a que mais sofreu os efeitos devastadores do processo colonizador, onde o idioma e a cultura dominantes foram impostos e as culturas de povos tão diversos, aniquiladas. (BONNICI, 2009, p. 263).
\end{abstract}

Como salientado por ele, a sociedade caribenha passou por um processo em que a cultura e o idioma foram apagados pela cultura dominante do colonizador, atitude de imposição de poder utilizada nos processos de colonização conhecidos. Com essa atitude, povos, culturas e tradições heterogêneas e diversas foram aniquiladas por um processo de aculturação e de apagamento, numa homogeneização ou dinâmicas de silenciamento e de invisibilização. 
No primeiro capítulo de Omeros temos descrita uma cena de desmatamento da floresta para a produção de barcos, o que bem representa, metaforicamente, esse processo de imposição cultural e linguística do colonizador sobre o colonizado:

\author{
Os anciãos barbados suportavam a dizimação \\ de sua tribo sem proferirem uma sílaba sequer \\ daquela língua que haviam falado como uma nação, \\ a língua ensinada aos rebentos [...] (WALCOTT, 1994, p. 33).
}

Na maioria das vezes, o processo de colonização é feito por meio do uso de violência e imposição, como foi o caso de Saint Lucia, ilha que faz parte das Pequenas Antilhas. A história de Saint Lucia está interligada com a história do próprio arquipélago ao qual pertence, pois passaram pelo processo de povoamento inicial pelos arauaques e pelos caribes. O arquipélago foi "achado" durante a última viagem de Colombo a América.

Violentamente ocorreu o início do processo de colonização francesa, com o extermínio dos índios que moravam naquelas terras e o início do tráfico de escravos negros que eram retirados da África; mas a colonização passou então pelo assédio britânico, em seguida. Quanto ao local onde a história é situada, "Saint Lucia, depois de mudar de dono catorze vezes, acabou passando definitivamente para a Grã-Bretanha em 1814, com a assinatura do Tratado de Paris." (VIZIOLI, 1994, p. 13).

Com toda essa história de mudanças durante os processos de construção do que é Saint Lucia atualmente, o poema de Walcott representa através dos arquétipos recorrentes na sociedade os mitos universais presentes no inconsciente coletivo social de toda a humanidade. São os pescadores daquela ilha que buscam sobreviver às dificuldades lutando por sua identidade e integração sociais. Portanto, através desta busca identitária, “de um e de todos os indivíduos, de uma e de todas as raças" (VIZIOLI, 1994, p. 8), que Derek Walcott consegue representar a própria condição humana por meio de seus personagens em seu poema.

A perda identitária e, por conseguinte, a sua busca são questões do povo representado pelo poeta, mas são, também, a sua própria busca. Nascido entre duas etnias e culturas, por ser mestiço/mulato, nunca se sentiu pertencente de fato a nenhuma delas, pois

Como mulato, nunca pôde ser aceito integralmente pela sociedade branca anglosaxônica da Inglaterra e dos Estados Unidos; por outro lado, nem sempre tem sido compreendido pela comunidade negra, devido às suas posturas moderadas em face do 
problema racial. Como descendente de africanos, busca, a exemplo de outros autores caribenhos, reencontrar sua identidade nos costumes oriundos do golfo de Guiné, até mesmo nas tradições tribais de seus antepassados negros; como descendente de brancos, não deseja desligar-se da herança cultural deixada pelos colonizadores de Saint Lucia. (VIZIOLI, 1994, p. 6-7).

Como percebido, o autor passa por uma complexa busca por identidade, pois, como mulato, pretende ter um pouco das duas heranças - característica presente no contexto diaspórico (HALL, 1994; 2003). Embora esteja inserido nas duas realidades, como frisado por Vizioli, Walcott não se sente "aceito integralmente pela sociedade branca anglo-saxônica da Inglaterra e dos Estados Unidos", o que corrobora com o apresentado por Bonnici (2009) de que a sociedade impõe limites nas relações hierárquicas a partir dos surgimentos de fatores relacionados à raça.

Tais fatores raciais colaboram, pois, para a própria necessidade de integração social, a busca por pertencimento, por resgate de origens de sua história. Essa busca, portanto, é o norteador em Omeros: “Quem vai nos ensinar uma história da qual também somos capazes?" (WALCOTT, 1994, p. 192).

Assim como o poeta, o personagem Achille, herói da obra, busca por sua identidade, porque não se sente pertencente àquela sociedade na qual vive. Ele é traído no amor, assim como o povo negro que vive ali em Saint Lucia, que foi enganado pelos colonizadores quando trazido para aquelas terras. A história de Achille por muitas vezes se confunde com a história de seu povo e do autor do poema.

A maior parte da narrativa é retratada numa aldeia de pescadores, situada na costa ocidental da ilha, próxima à capital. Lá, estão os pescadores Achille e Hector, ambos negros, que se odeiam - apesar de terem admiração um pelo outro, em segredo - e lutam pelo coração da bela Helen. Dentre os dois, Achille é o mais forte e busca a todo custo conquistar esse amor. Ela é uma bela “[...] criada negra de olhos amendoados” (VIZIOLI, 1994, p. 16), que é disputada pelos dois rapazes.

O companheiro de Achille é o negro Philoctete, que possui em sua perna uma ferida aberta, causada por uma âncora e, aparentemente, sem cura. O amigo do herói “[...] não sofre num retiro isolado, mas na presença de toda a comunidade (o que sugere que sua chaga é, simbolicamente, a de seu povo)" (VIZIOLI, 1994, p. 17). Como explicado pelo prefacista, a 
ferida de sua perna é uma metáfora para o sofrimento de seu povo, o povo de Saint Lucia. Acerca dessa ferida, Walcott escreveu:

Por algum dinheiro extra, sob uma amendoeira marinha, ele lhes mostra uma cicatriz feita por uma âncora enferrujada, enrolando uma perna das calças com o lamento ascendente

de uma concha. Ela ficou enrugada como a corola de um ouriço-cacheiro. Não explica a sua cura.

'Tem coisas', sorri, 'que valem mais do que um dólar.' (WALCOTT, 1994, p. 31, grifos nossos)

Como dito pelo escritor, a ferida de Philoctete não tem sua cura explicada, pois também sua ilha e seu povo passam por uma busca de identidade e encontro com a cura para os processos da colonização e sofrimento vividos.

Numa cena descrita em Omeros, o personagem segue com seu facão para as plantações de inhame; uma cena bastante simbólica, que vem a seguir:

Philoctete ali coxeou para a sua plantação de inhame. Atravessou a propriedade tremendo, embalando o seu facão, [...]

Pensar em velas trouxe-lhe a idéia de sua própria morte.

O vento virava as folhas do inhame, iguais a mapas da África, suas veias sangravam branco $[\ldots]$

Estendeu o pé. Escorregou o aço cortante como navalha por entre o polegar e o dedo apelador. As folhas de inhame

[encolheram-se

num frio suor. Ele talhou todas as raízes na altura do calcanhar.

Talhou-as no calcanhar, notando como se enrolavam, cabeças caídas, sem suas raízes. Maldisse os inhames:

Vocês todos vêem como é estar sem raízes neste mundo?”

Então soluçou, com o rosto voltado para as folhas trucidadas. De seus talos abertos gotejou uma seiva igual à sua própria dor. (WALCOTT, 1994, p. 45-46).

Ao se observar o campo semântico presente no excerto selecionado, tem-se que as palavras referentes ao cultivo e ao momento em que talhava os inhames e suas folhas todas representam uma proximidade com a terra, inclusive o próprio tubérculo - ou raiz. Outra metáfora existente na estrofe é o verso "O vento virava as folhas do inhame, iguais a mapas da África" (WALCOTT, 1994, p. 45), que, unido aos versos "[...] As folhas do inhame encolheram-se / num frio suor [...]” (WALCOTT, 1994, p. 46), mostra a busca pela raiz 
africana. Pode-se perceber também que sua ferida é uma representação da busca por identidade e retorno às origens, comprovada e consolidada por meio do verso "Vocês todos veem como é estar sem raízes neste mundo?'”, uma fala que bem representa a busca dele, de Achille e de Walcott por essa resposta.

De fato, a obra Omeros é "recheada" de metáforas. Além da simbologia da ferida na perna de Philoctete, existe ainda a figura das formigas como parte integrante da lista de metáforas utilizadas, sendo essa uma das mais importantes para a história narrada. Por diversas vezes, Derek Walcott utiliza as formigas como comparação para os trabalhos braçais realizados pelo povo de sua ilha. Em uma dessas ocorrências, ele narra que "[...] Trabalhavam com a mesma concentração / que um exército de formigas lava-pés.” (WALCOTT, 1994, p. 34). Já em outro momento, a comparação fica completa ao trazer o sentido com uma nova comparação feita:

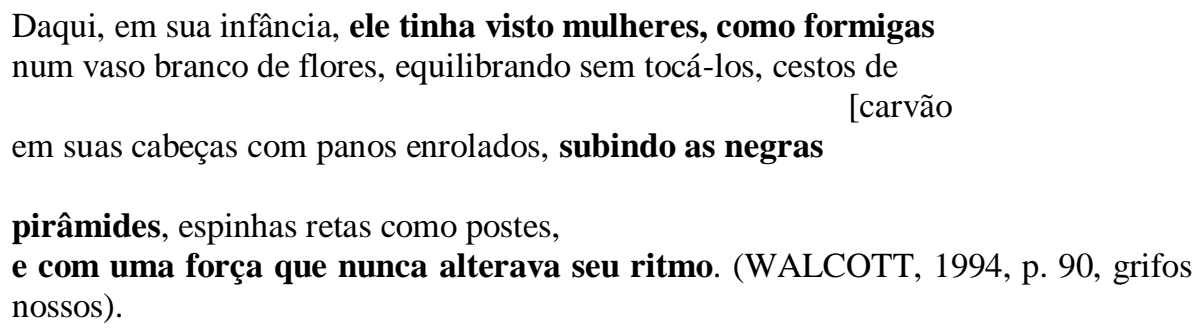

Como grifado, ao comparar às mulheres e às pirâmides, ele consegue esclarecer a utilização anterior da metáfora das formigas. Elas, as formigas, sempre significaram a metáfora dos negros, trabalhadores braçais, a raça considerada inferior e naturalmente trabalhadora, como já citado por Bonnici (2009). Porém, a simbologia utilizada ainda sobressai, além da situação de trabalho, a força daquelas mulheres, com seus panos enrolados nas cabeças, carregando o carvão em filas enormes, que formavam pirâmides e "com uma força que nunca alterava o ritmo."

A metáfora das formigas era nada mais do que parte da história de Saint Lucia representada em sua epopeia. Elas representavam as filas imensas de mulheres que levavam carvão aos navios atracados na capital, Castries - um dos ciclos de exploração econômica durante a colonização. Essa prática perdurou até o século XIX e, por isso, tem destaque na obra de Walcott. 
O poeta sabia seu papel de representante de um povo que buscava sua identidade e que muito havia sofrido,

Ele falava por aquelas Helens de uma época anterior:

"O inferno foi levantado naqueles montes. Naquele país de carvão sem fogo, naquele reino diabólico da mesma cor de suas peles e sombras, cada alma mourejante

subia com seu cesto de um quintal [...]

"O que o Tempo decidiu fazer, ao longo deste molhe enegrecido de carvão, com meu corpo traiçoeiro depois disto", disse ele, olhando as mulheres, "ficará em sua mente tanto tempo

quanto uma pergunta que você não tem o direito de fazer (WALCOTT, 1994, p. 9092, grifos nossos).

Como dito no primeiro verso da citação, aquela era a fala das Helens de outra época, aquele era um canto coletivo. Naquele local de exploração do carvão, representado quase que como um inferno (termos grifados), as memórias teriam uma grande duração - essas histórias jamais seriam esquecidas. Na verdade, seriam eternizadas através daquela epopeia das Antilhas.

\section{Processos de visibilidade: a outrização produtiva nas obras analisadas}

O colonizado fala quando se transforma num ser politicamente consciente que enfrenta o opressor.

Thomas Bonnici, "Teoria e crítica pós-colonialistas"

Tendo em vista que outrização (SPIVAK, 1994) é o enaltecimento social da identidade de um grupo e o rebaixamento violento de outro, o conceito-atitude de outrização produtiva (CARVALHO, 2012) é, portanto, uma abordagem ressignificada dos processos de colonização, apagamento e silenciamento das culturas de territórios geográficos e imaginados.

Na prática, a outrização produtiva na narrativa de Tenda dos Milagres ocorre em dupla interface: a primeira, pelo candomblé e sua força de expressão dos negros; a segunda, através do próprio personagem Pedro Archanjo, antes tão odiado e silenciado, após sua morte tão homenageado.

Mas essa notoriedade de Pedro Archanjo não vem facilmente. Após escrever e publicar seus quatro livros, ele enviou diversos exemplares para universidades e bibliotecas nacionais e 
internacionais. Se não o tivesse feito, "Levenson não os teria descoberto. Em Salvador, apenas alguns etnólogos e antropólogos sabiam deles, a maioria por ouvir dizer" (AMADO, 2008, p. 28). Poucos eram os reais conhecedores dos feitos científicos de Archanjo, embora ele houvesse tentado de todo modo fazer a divulgação das obras por meio dos diversos envios feitos dos exemplares.

Dr. James D. Levenson, prêmio Nobel de Ciência, considerado "um dos cinco gênios do nosso século', segundo a Enciclopédia Britânica: filósofo, matemático, sociólogo, antropólogo, etnólogo, muita coisa mais, professor da Columbia University" (AMADO, 2008, p. 25) quem apresentou Pedro Archanjo ao seu próprio país. Através desse pesquisador internacional, os estudos de Archanjo passaram a estar no mesmo nível, ao menos para alguns, que os demais estudos científicos. O reconhecimento público e admiração dos grandes estudiosos só veio após a sua morte e por intermédio de uma estrela internacional do ramo científico. Além de Archanjo,

[...] nenhuma figura intelectual gozou de tamanha evidência, nenhuma outra obra obteve os elogios concedidos aos seus quatro pequenos volumes, reimpressos às carreiras, livros por tantos lustros esquecidos, ou melhor: desconhecidos não só da massa de leitores mas também dos especialistas - com as costumeiras e honrosas exceções das quais logo se dará notícia. (AMADO, 2008, p. 25, grifos nossos).

Como evidenciado através dos grifos na fala do narrador, poucos eram os estudiosos que realmente conheciam as obras de Pedro, apesar de vários outros terem "ouvido falar". No entanto, após a sua "apresentação" ao Brasil pelo estrangeiro, se tornou uma referência nos estudos da vida popular e das influências africanas na sociedade baiana da época. Sendo assim, seus livros foram reimpressos às pressas e divulgados aos quatro cantos por causa da aproximação de seu centenário.

Embora mestiço, considerado inferior pela sociedade que estava embriagada pelos conceitos cientificistas de raça e arianismo, mas com a "permissão" do vencedor do prêmio Nobel, portador de poder, Pedro Archanjo passou a ter voz e vez na sociedade. Foram as declarações de Levenson que

COLOCARAM AS PÁGINAS DAS GAZETAS, os microfones das rádios, as câmaras de tevê a serviço da memória e da obra do baiano até então desconhecido de súbito celebridade internacional. Reportagens, entrevistas, pronunciamentos dos bambambãs da cultura, artigos nos suplementos domingueiros, crônicas, mesasredondas nos programas de maior audiência. 
Em geral os intelectuais, nas entrevistas e nos artigos, no rádio e na televisão, buscaram sobretudo provar íntimo contato, de longa data, com a obra de Archanjo. (AMADO, 2008, p. 54, grifos do autor).

Como já dito, poucos eram os que, de fato, tiveram contato com Archanjo ou suas obras antes da divulgação feita por Levenson, mas os intelectuais e pessoas da mídia buscavam "sobretudo provar íntimo contato, de longa data, com a obra" dele. Foi uma entrevista concedida pelo professor Azevedo que serviu como fonte principal para acesso aos conteúdos vinculados a Pedro Archanjo. Em sua entrevista, o professor Azevedo,

\footnotetext{
Meticuloso, explicou, analisou, detalhou a obra do autor de Influências africanas nos costumes da Bahia, realçando seu autodidatismo, sua seriedade e sua coragem científicas, espantosas para a época. Citou títulos, trechos, locais de pesquisa, nomes, datas, disse alguma coisa sobre o homem, com quem tivera breve contato e a cujo enterro comparecera. (AMADO, 2008, p. 55).
}

A partir dessa entrevista, muitos ensaios, artigos e crônicas surgiram; nenhum deles citou o professor Azevedo, no entanto, todos citaram Levenson e outros autores europeus. Além daquelas informações, o entrevistado ainda "[...] dera conta do imenso sacrifício feito pelo paupérrimo bedel, de ordenado parco e cachaça longa, para imprimir seus livros." (AMADO, 2008, p. 55), além de citar o apoio do amigo Lídio Corró, que montou uma pequena tipografia na ladeira do Tabuão, onde imprimia diversos produtos, como os anúncios de lojas e literatura de cordel para vendas em mercados e feiras. Nessa tipografia que "[...] foram compostos e impressos três dos quatro volumes do ignorado mestre, todos de péssima qualidade gráfica." (AMADO, 2008, p. 56).

Um dos quatro livros de Pedro Archanjo teve uma tiragem de mil exemplares com um editor responsável pela publicação. As outras três edições de suas obras tiveram tiragens menores que trezentas cópias; a última, “[...] a dos importantíssimos Apontamentos sobre a mestiçagem das famílias baianas, imprimiram-se apenas cento e quarenta e dois volumes, para mais não dera o papel." (AMADO, 2008, p. 56, grifos do autor). Mesmo sendo tão poucos, foram suficientes para causar "escândalo, horror e violência", inclusive causando a atuação da polícia no impedimento de nova tiragem. Embora tenha acontecido o impedimento de uma nova tiragem, a quantidade inicial foi suficiente para fazer chegar às mãos de pessoas importantes, 
como o doutor Levenson, que assumiu um papel importantíssimo no enredo do livro de Jorge Amado.

Como já dito, a outrização produtiva em Tenda dos Milagres ocorre em dupla interface e uma delas é a importância do candomblé como força de expressão dos negros que está representada na narrativa por meio das cenas descritas do candomblé e dos afoxés carnavalescos. Apesar de impedidos de sair às ruas, o Afoxé dos Filhos da Bahia saiu e, assim, o público

[...] VEIO CORRENDO PARA VER E BATIA PALMAS, GRITAVA, A PULAR E A DANÇAR, em louco entusiasmo. Veio o entrudo inteiro: máscaras, zé-pereiras, mandus, zabumbas, fantasias, blocos, cordões, esfarrapados, cabeçorras, caretas. Quando o afoxé despontou no Politeama, ouviu-se um grito uníssono de saudação, um clamor de aplauso: viva, viva, vivoô! (AMADO, 2008, p. 67, grifos do autor).

O povo esteve muito animado durante a passagem do afoxé com todas as suas ornamentações e máscaras; todos estavam em ritmo de aplausos e surpresos com a saída do afoxé às ruas mesmo estando sob proibição expressa do "[...] dr. Francisco Antônio de Castro Loureiro, diretor interino da Secretaria de Polícia".

Como indicado na epígrafe que abre esta seção, é através da consciência política que o colonizado passa a falar. Portanto, é possível considerar que o afoxé representado na literatura amadiana é a forma de expressão de visibilidade possível aos negros e mestiços que o compunha. Sobre o afoxé e sua ousadia de ir à rua é dito que

[...] nunca saíra antes e jamais se concebera e vira afoxé assim de majestade, de figuração tão grande e bela, com batuque igual, maravilha de cores, ordem admirável e Zumbi em sua grandeza.

Numa ala, os guerreiros seminus, na outra os mercenários de Domingos Jorge Velho, o escravocrata, cabo de guerra sem dó nem piedade, sem lei e sem tratados. "Queroos vivos, a todos, para escravos", anunciava em seu discurso ao povo da Bahia, no Carnaval. (AMADO, 2008, p. 67).

Toda aquela alegoria e colorido do carnaval fascinava o povo que ali estava. Eles aplaudiam, animados, tanto pelo que viam e ouviam quanto pelo desafio de saírem a rua estando proibidos. O afoxé foi narrado como o entretenimento da classe baixa, como uma "fuga" da realidade pesada que viviam: "Parece-vos pouco a miséria, a falta de comida e de trabalho, as doenças, a bexiga, a febre maldita, a maleita, a disenteria a matar meninos, ainda quereis, sr. dr. Francisco Antônio Mata Negros, empobrecê-lo mais e reduzi-lo.” (AMADO, 2008, p. 68). 
As condições de vida dos negros e mestiços daquela sociedade não eram das melhores. Muitos eram os desafios, as doenças, as dificuldades; o afoxé, portanto, seria o espaço de representação de suas lutas, um momento de descontração, de irreverência e liberdade. Com a invasão da polícia, o narrador começa a questionar "[...] onde já se viu, sr. dr. Francisco Antônio de Castro Loureiro, interino da polícia e branco de cu preto, onde já se viu Carnaval sem afoxé, brinquedo do povo pobre, do mais pobre, seu teatro e seu balé, sua representação?”. Por conta desse impedimento, para o chefe de polícia restaram apenas as vaias, risadas e assovios, enquanto que, para o afoxé, as palmas e os vivas.

A ousadia do afoxé e a defesa do público são entendidas como formas de outrização produtiva, pois representam o não-silenciamento, o posicionamento e ressignificação do que viveram e passaram durante os tempos de prática carnavalesca. Essa atitude renderia, alguns anos depois, a liberação total da participação dos afoxés nos carnavais soteropolitanos.

Sobre a chegada da cavalaria da polícia e o encontro entre o afoxé e o dr. Francisco Antônio, o narrador informa que

\footnotetext{
O povo reagiu, na defesa do afoxé, morra Chico Cagão, morra a intolerância. A batalha se estendeu, os cavalarianos desembainharam as espadas, foram batendo, pisando e derrubando nas patas dos cavalos - o afoxé dissolveu-se na multidão. Gritos e ais, morras e vivas, gente machucada, correrias, quedas, trompaços, alguns guerreiros presos pelos esbirros, soltos pelo povo contumaz na briga e na folia. [...]

- Prendam aquele pardo, ele é o cabeça de tudo.

Mas o pardo cabeça de tudo, Pedro Archanjo, sumira num beco, ladeira abaixo, com mais dois. (AMADO, 2008, p. 68, grifos nossos).
}

Estão representados nesse excerto as duas atitudes aqui analisadas: a outrização - ou invisibilidade - e a outrização produtiva - ou visibilidade. Os grifos salientam a violência sofrida pelo povo presente no afoxé que é a representação da outrização, enquanto a resistência aos ataques e violência são a clara representação da outrização produtiva e uma metáfora das relações existentes na sociedade desde a escravidão.

O fator raça está sinalizado na fala do policial que grita a prisão daquele "pardo". Mas, Pedro Archanjo já havia sumido por entre os becos das ruas do Pelourinho e os três foram correndo em disparada. Então, ele, "[...] simples guerreiro de Palmares e chefe da baderna, susteve a maratona e começou a rir, a rir às bandeiras despregadas, um riso alto, claro e bom de 
quem rompera a ordem injusta e proclamara a festa; abaixo o despotismo, viva o povo [...]" (AMADO, 2008, p. 69).

Além de suas participações nos afoxés e da escrita dos quatro livros, muitas cartas de denúncia e reclamações eram escritas e enviadas para diversos jornais e revistas, nas quais “[...] exigia que lhes fossem assegurados 'a liberdade, o respeito e os privilégios concedidos às religiões católica e protestante, pois os cultos afro-brasileiros são a fé, a crença, o alimento espiritual de milhares de cidadãos tão dignos quanto os que mais o sejam'." (AMADO, 2008, p. 170). Esses processos de divulgação e busca por direitos são, portanto, uma busca por espaço de representação, uma busca por voz e oportunidades; isto é, outrização produtiva. A promoção dessa visibilidade ocorre, então, para as culturas tradicionalmente silenciadas pela sociedade.

Assim como Pedro Archanjo buscou representar seu povo e suas origens na obra de Jorge Amado, Derek Walcott assume um papel de grande importância ao escrever Omeros, por sua representatividade e "[...] promoção e visibilidade para culturas tradicionalmente silenciadas pela crítica literária internacional especializada." (CARVALHO, 2012, p. 99). De modo reiterado, o poema de Walcott, além da narrativa da história de Saint Lucia, é a busca de identidade de seu povo. Esse sentimento de "falta" de identidade é entendido como um processo de invisibilização (outrização) sofrido; no entanto, o resultado de sua busca é considerado como outrização produtiva.

A representação dessa busca está mais bem representada por meio dos personagens Achille e Philoctete. O último, pela ferida em sua perna (incurável, causada por uma âncora) que é uma metáfora para o ferimento das próprias Antilhas, portanto “[...] sua cura se prende à recuperação da herança africana.” (VIZIOLI, 1994, p. 20).

Ma Kilman - uma negra que toma conta do bar mais antigo da vila e é vista como curandeira ou guardiã por conta de suas práticas religiosas - encontra a semente vinda da África com o andorinhão - Um andorinhão carregara em seu estômago a forte semente, / séculos atrás [...] (WALCOTT, 1994, p. 227) -, quando ela é conduzida a encontrá-la. Na verdade, foi guiada, inicialmente, por um cheiro e, em seguida, percebe a atuação das formigas no trajeto:

[...] Ela então cambaleou para trás

diante da fileira de formigas a seus pés. Viu o caminho que haviam seguido às suas costas, acompanhando-a desde a

[igreja, 
sinalizando uma língua que ela não reconhecia. (WALCOTT, 1994, p. 227, grifos nossos).

Apenas em primeiro momento Ma Kilman não conhecia essa língua das formigas, mas, após o contato com a semente africana trazida pelo andorinhão, ela passou a ter contato com as formigas que correram

$$
\begin{aligned}
& {[\ldots] \text { sobre as mechas duras como arame, barrando-se mutuamente, e }} \\
& \text { uma para outra a mesma mensagem com bracinhos } \\
& \text { [rabiscadores } \\
& \text { e testa tocando testa. Ma Kilman curvou a sua para a frente, } \\
& \text { e, enquanto seus lábios se moviam com as formigas, }[. . .]
\end{aligned}
$$

ouviu as formigas falando a linguagem de sua bisavó [...] (WALCOTT, 1994, p. 231-232, grifos nossos).

A partir do momento do "achamento" da semente vinda da África, deu-se então a cura da ferida de Philoctete. Essa semente simboliza o reencontro possível com as origens, o fim da busca pela identidade, a ressignificação dos processos e a consumação da outrização produtiva. Além da saúde, Philoctete recupera “[...] os sentimentos e as virtudes de sua raça." (VIZIOLI, 1994, p. 20).

Além das formas de outrização produtiva apresentadas aqui, ainda há a questão da autoria como processo de visibilidade, pois os autores dessas obras escrevem possibilitando voz e vez aos povos representados literariamente e permitem, através de sua autoria, que sejam vistos, ressignificando o processo sofrido de invisibilidade. Essa modalidade de outrização produtiva será apresentada a seguir.

\section{Outrização produtiva e autoria: o narrador pós-colonial}

Mostro-me para sair do exílio onde me colocaram e tiraram minha voz [...] Rebelei-me, afinal fui feita livre e queria iguais direitos 
A outrização produtiva também está presente na posição da autoria, representada pelo narrador pós-colonial (CARVALHO, 2009), que assume uma posição de coletividade, mesmo quando narra o vivido por ele mesmo, pois não se subtrai da ação narrada. Através de sua ficção, muitas vezes quem é silenciado passa a ser ouvido, a ter voz.

Em Omeros, Derek Walcott faz perguntas que permitem uma reflexão sobre o posicionamento do Caribe como periferia do binômio centro e periferia, ou colonizador e colonizado, além dos questionamentos que faz sobre esse poder central que determina a dependência hierárquica entre centro/colonizador em posição superior e periferia/colonizado abaixo daqueles.

No poema de Walcott é possível perceber que o narrador, apesar de, por vezes, apresentar um posicionamento pessoal na narrativa, também traz uma polifonia, permitindo que os outros silenciados tenham voz e vez dentro da narrativa. Essa atitude confirma a análise de um "nós", uma coletividade, uma fala "junto".

Walcott assumiu o papel de poeta, numa perspectiva de narrador pós-colonial, daquele que fala por si, mas que assume um significado de eu-nós, assim como Neuzamaria Kerner argumenta que ela "[...] imaginava mesmo era dar voz a quem foi tirada a vez de falar, de defender-se [...]" (KERNER, 2014, p. 24).

Assim como Walcott busca uma identidade por meio da narrativa da história de Saint Lucia em Omeros, Jorge Amado escreve Tenda dos Milagres para assumir um posicionamento acerca (também) da identidade, mas, nesse caso, para determinar que a verdadeira identidade nacional brasileira seria a mestiçagem.

Em Omeros, o próprio autor "comparece para falar de sua busca particular de identidade, como mulato, como antilhano, como homem e como poeta de uma língua que [...] foi dos dominadores ingleses antes de ser sua.” (VIZIOLI, 1994, p. 19). Na obra, Walcott está presente tanto por meio do narrador quanto pelos personagens que buscam uma identidade, assim como ele, assim como, por projeção, representam a condição de Saint Lucia e de todos os homens.

Assim como Kerner, o narrador do poema mostra sua intenção de dar voz aos personagens narrados, àqueles pés cansados das negras, que tanto carregavam carvão em filas enormes, por diversas vezes representadas metaforicamente pelas formigas: 
depois de havê-las contemplado da casa de seus avós como criança ferida por sua força e beleza,

é o de usar a oportunidade de dar a esses pés, uma voz.

(WALCOTT, 1994, p. 92, grifos nossos).

\section{0 fim?}

[...] não recuamos nunca, e não abrimos mão de nosso direito, vivemos para exercê-lo.

Jorge Amado, Tenda dos Milagres

Por meio do estudo das (in)visibilidades identitárias foi possível comprovar que a outrização - forma de silenciamento e subalternidade de um grupo ou cultura - está presente nas duas obras que constituem o corpus de pesquisa. Através de Omeros, Derek Walcott foi capaz de narrar a história de Saint Lucia, além de objetivar uma busca pessoal por identidade, representando essa busca por meio de arquétipos sociais que constituíam seus personagens principais.

Jorge Amado discutiu a questão do silenciamento dos mestiços e negros na sociedade baiano-brasileira representada em Tenda dos Milagres, em que o fator raça era determinante para as relações sociais, haja vista que a sociedade da época estava impregnada pelas ideias cientificistas de raças superiores e inferiores. Além disso, ainda incorriam os fechamentos dos afoxés - representações carnavalescas de cultura do candomblé.

Em contraponto a essa interface de invisibilidade, há a outrização produtiva - processo de ressignificação do silenciamento e estigma e possibilidade de representação e voz nas obras literárias estudadas. Essas oportunidades de visibilidade ocorrem por meio da resistência e luta dos grupos sociais anteriormente rebaixados e, ainda, pela posição de autoria dos escritores das obras em estudo.

Derek Walcott, ao escrever o poema, abordou uma busca pessoal por identidade, mas sua busca era também a representação pós-colonial dos anseios de seu povo, de Saint Lucia e todos os homens. Jorge Amado, ao retratar o mulato Pedro Archanjo e os demais personagens a ele ligados, também tratou da questão da identidade, mas numa postura de assumir uma identidade nacional que, a seu ver, teria realmente a mestiçagem como emblema. 
Em suma, das duas obras é possível alcançar um ponto em comum: as identidades dos grupos sociais devem ser sempre buscadas e mantidas, pois fazem parte de cada um daqueles personagens, de suas nações e de toda a humanidade. Ruy Póvoas diz que "[...] por isso que as minorias têm que cobrar, organizadamente, o reconhecimento da legitimidade de suas memórias, como parte integrante da memória nacional.” (PÓVOAS, 2010, p. 48). Certamente, essas cobranças foram feitas por seus representantes literários e eternizadas por meio de suas obras.

\section{Referências}

AMADO, Jorge. Tenda dos milagres. São Paulo: Companhia das Letras, 2008.

BASTIDE, Roger. O Candomblé da Bahia. Trad. de Maria Isaura Pereira de Queiroz. São Paulo: Companhia das Letras, 2001.

BONNICI, Thomas. Teoria e crítica pós-colonialistas. In: BONNICI, Thomas; ZOLIN, Lúcia Osana. Teoria literária: abordagens históricas e tendências contemporâneas. Maringá: Edvem, 2009. p. 257-284.

CARVALHO, Isaias Francisco de. Omeros e Viva o povo brasileiro: outrização produtiva e identidades diaspóricas no Caribe Estendido. 179 f. 2012. Tese (Doutorado) - Instituto de Letras, Universidade Federal da Bahia, Salvador, 2012.

CARVALHO, I. F. O narrador pós-colonial. In: CONGRESSO NACIONAL DE LINGUAGENS E REPRESENTAÇÕES: LINGUAGENS E LEITURAS, 1, 2009, Ilhéus/BA. Anais... Ilhéus/BA, 2009. Disponível em: <http://www.uesc.br/eventos/iconlireanais/ iconlire_anais/anais-19.pdf>. Acesso em: 12 ago. 2015.

KERNER, Neuzamaria. O livro-arbítrio das Evas: dentro e fora do jardim. Ilhéus: Editus, 2014.

HALL, Stuart. Cultural identity and diaspora. In: . Colonial discourse and post-colonial theory: a reader. Edited and introduced by Patrick Williams and Laura Chrisman. New York: Columbia University Press, 1994. p. 392-403.

HALL, Stuart. Da diáspora: identidades e mediações culturais. Org. Liv Sovik; Trad. Adelaine La Guardia Resende et al. Belo Horizonte: Editora UFMG; Representação da UNESCO no Brasil, 2003.

MEMMI, Albert. Retrato do colonizado precedido de Retrato de colonizador. Prefácio de JeanPaul Sartre. Trad. de Marcelo Jacques de Moraes. Rio de Janeiro: Civilização Brasileira, 2007. 
PÓVOAS, Ruy do Carmo. A memória do feminino no candomblé: tecelagem e padronização do tecido social do povo de terreiro. Ilhéus, Editus, 2010.

SPIVAK, Gayatri Chakravorty. Can the subaltern speak? In: WILLIAMS, Patrick; CHRISMAN, Laura (Eds.). Colonial discourse and post-colonial theory: a reader. New York: Columbia University Press, 1994. p. 66-111.

VIEIRA, Antônio. Akará-jé o mesmo que comer fogo. 2. ed. [S.1.]: Espaço cultural Inácio da Catingueira, 2005.

VIZIOLI, Paulo. Omeros: a epopéia das Antilhas. In: WALCOTT, Derek. Omeros. Pref. e Trad. de Paulo Vizioli. São Paulo: Companhia das Letras, 1994.

WALCOTT, Derek. Omeros. Pref. e Trad. de Paulo Vizioli. São Paulo: Cia das Letras, 1994.

WALLERSTEIN, Immanuel. The modern world-system: capitalist agriculture and the origin of the European world-economy in the sixteenth century. New York: Academic Press, 1974.

Recebido em 29 de dezembro de 2018. Aceito para publicação em 15 de abril de 2019. 